\title{
FOAL REJECTION - CHARACTERISTICS AND THERAPY OF INADEQUATE MATERNAL BEHAVIOUR IN MARES
}

\author{
Urszula Żurek, Janusz Danek \\ Department of Animal Reproduction and Animal Health Protection, \\ University of Technology and Life Sciences, 85-225 Bydgoszcz, Poland
}

\begin{abstract}
The bond between the mare and her newborn foal is usually a strong one. However, some factors can lead to aberrations of maternal behaviour. Failure to protect and nurse the foal is defined as foal rejection. With a long period of gestation and increasingly high value of foals, foal rejection causes severe losses to breeders. Horse owners and breeders should have knowledge of risk factors, types, prevention rules and treatment of inadequate maternal behaviour. In the case of foal rejection it is important to use fostering techniques in raising such foals.
\end{abstract}

Key words: mare, foal, maternal behaviour, orphan foal

Parturition in mares is rapid and followed by a period of forming a specific social bond between the dam and her neonate (Crowell-Davis and Houpt, 1986). Maternal instinct dictates the mare behaviours aimed at protecting and nursing the neonate (Houpt, 2009; Żurek and Danek, 2011 a). The specific bond between the mare and her foal may take some time to develop but is usually a strong one (Mellor and Stafford, 2004; Houpt, 2009). There is high individual variation in normal maternal behaviour, but normally mares actively defend their foals, tolerate or assist nursing, do not injure their own foals, and remain near them, even when they are at pasture (Crowell-Davis and Houpt, 1986; Houpt, 2009; Żurek and Danek, 2011 b). It is therefore uncommon when a mare is afraid of her neonate or even attacks it (Houpt, 2009).

Foal rejection occurs when a mare refuses to nurse her foal and has an aggressive attitude towards it (Juarbe-Diaz et al., 1998). Foal-rejecting behaviours include avoiding, threatening, squealing, chasing, biting and kicking foals. While $82 \%$ of dams lick their foals after parturition, only $38 \%$ of rejecting mares do so. Sometimes mares squeal at their foals, but only rejecting mares chase their neonates. Normal maternal behaviours include kick threats, but actually most rejecting mares (88\%) kick their foals (Houpt, 2009). 
Foal rejection can lead to starvation of the neonate (Mellor and Stafford, 2004). In the case of foal-rejecting mares, nutritional and behavioural needs of the neonate are not met (Juarbe-Diaz et al., 1998). Health of the rejected foal is in danger because the transfer of passive immunity fails. Before gut closure occurs the foal has to consume an adequate volume of good quality colostrum, whereas it is not possible when a mare refuses to nurse (Juarbe-Diaz et al., 1998; Houpt, 2009).

Although foal rejection is uncommon, it can be difficult to resolve and leads to a loss of time and money for the mare's owner. The results of a questionnaire from owners of foal-rejecting mares showed that one out of 20 rejecting mares had injured or killed their foals within a few days after parturition (Juarbe-Diaz et al., 1998). The aim of this article is to briefly review the causes and types of foal rejection, intervention and prevention of abnormal maternal behaviour and some methods of rearing the orphan foal.

\section{Risk factors of foal rejection}

Causes of abnormal maternal behaviour in horses are not well understood (Juarbe-Diaz et al., 1998). Foal rejection can occur in either primiparous or multiparous mares, but it is believed that abnormal maternal behaviour is more common in mares that have a foal for the first time. It results from the lack of maternal experience in primiparous mares (Mellor and Stafford, 2004; Grogan and McDonnell, 2005; Houpt, 2009). It is suspected that foal rejection has a genetic aspect. A high prevalence $(5.1 \%)$ of foal rejection was found in purebred Arabian mares (JuarbeDiaz et al., 1998; Houpt, 2010). The possibility of foal rejection is even higher if foal rejection had also been observed in the paternal grandmother of a given Arabian mare (Houpt, 2009).

Although the number of humans present at foaling is not a risk factor for rejection, premature human intervention during the early imprinting period should be avoided because it can predispose a mare to rejection of her neonate (Crowell-Davis and Houpt, 1986; Mellor and Stafford, 2004; Houpt, 2009). Also pain and stress connected with passing the placenta, postpartum shock, mastitis, agalactia or unknown pathology of the mammary system may result in aggression towards the foal (Pawlak and Doroz, 1998; Grogan and McDonnell, 2005; Houpt, 2010; Żurek and Danek, 2011 b).

Another risk factor of foal rejection is separation between the dam and her neonate, especially during the first hours after parturition, when the sensitive mare-foal bond is being formed (Mellor and Stafford, 2004; Houpt, 2009). When a foal is separated from the mare for treatment of a medical problem, the change in its odour or appearance (for example by clipping or bandaging) may influence the maternal behaviour of its dam (Houpt, 2010). Also hormonal imbalance seems to play a role in the development of a mare's maternal behaviour as has been found in sheep, rats and mice (Juarbe-Diaz et al., 1998). Mares that reject their foals have lower levels of progesterone before foaling than mares with normal maternal behaviour (Houpt, 2010).

As regards the risk of foal rejection, there are also some misconceptions. There is no correlation between breeding by artificial insemination and rejection of a foal 
(Juarbe-Diaz et al., 1998). Also, natural selection is not a reason for abnormal maternal behaviour. It is suggested that mares reject abnormal neonates that would not survive in the wild but in fact the mortality rate of rejected foals is $6 \%$. There is also no evidence that mares reject their foals because the mares have been rejected themselves as fillies (Houpt, 2009).

\section{Types and example of foal rejection}

There are several forms of foal rejection identified in mares (Crowell-Davis and Houpt, 1986). Each case of inadequate maternal behaviour should be studied individually but the first step in treatment of foal rejection is to understand the specific type (Crowell-Davis and Houpt, 1986; Grogan and McDonnell, 2005).

Grogan and McDonnell (2005) suggest the ambivalence of the dam towards her foal to be the most common form. This behaviour is connected with lack of attention, bonding and protective behaviour. It may be typical behaviour after dam-foal separation and when the mare or the foal is weak or medicated.

The most common type of abnormal maternal behaviour in primiparous mares is the fear of a foal (Grogan and McDonnell, 2005). Inexperienced mares can show the explosive fear of small creatures that suddenly have appeared at their side. The fearful dams try to escape from their neonates and avoid any contact with them. As a result, they can accidentally injure the foals by running over them (Crowell-Davis and Weeks, 2005; Grogan and McDonnell, 2005; Houpt, 2010).

Sometimes it seems that normal forming of the mare-foal bond occurs and the dam accepts and protects her neonate, but when it comes to suckling, she may show aggression towards the foal (Grogan and McDonnell, 2005; Houpt, 2009, 2010). The mare does not permit suckling and can squeal, avoid or even kick the foal if it persists (Grogan and McDonnell, 2005; Houpt, 2010). The cause of this behaviour is usually connected with discomfort in the mare (Grogan and McDonnell, 2005; Żurek and Danek, 2011 b). To be more specific, normal nursing can be disturbed by retained placenta, mastitis or udder edema (Crowell-Davis and Weeks, 2005; Grogan and McDonnell, 2005). Udder can be painful also because of the foal itself when it is bunting the udder or biting the teat (Grogan and McDonnell, 2005).

The most severe form of abnormal maternal behaviour is a savage attack on a foal. This rare behaviour may occur soon after foaling or some days later (Grogan and McDonnell, 2005). The dam actively attacks the foal, without the provocation of suckling attempts (Grogan and McDonnell, 2005; Houpt, 2009). What is interesting, some elements of normal maternal behaviour can be observed as well, for example tending or bonding behaviour (Grogan and McDonnell, 2005). Aggressive mares usually do not lick the fetal membranes or the foal (Houpt, 2010). A mare's head is lowered, the mare bites and grasps the foal and she may lift, shake, toss, or stamp and hold the neonate to ground (Grogan and McDonnell, 2005). The attacked foal can be injured mainly to the head, neck and limbs. Those injuries in the foal are caused more frequently by biting than kicking (Pluhacek and Bartos, 2000). Similar behaviour may be observed in an infanticidal stallion (Houpt, 2010). The stallion that attacks foals sired by another stallion, benefits from a mare returning from lactational anoestrus to a reproductive state (Cameron et al., 2003). It has not been explained yet 
why some dams actively attack their own foals. Risk factors can be both genetic and hormonal. Taking into account the fact that the savage attack is the most common in primiparous mares, lack of maternal experience seems to be the main reason (Grogan and McDonnell, 2005).

An interesting case of maternal rejection was studied by Houpt and Antczak (1998). A donkey mare was kicking and biting her neonatal foal which was only trying to suckle. The foal was hungry because the mare was not supplying enough milk. A lack of milk was caused by dehydration. The mare was provided with water but it was poured into a new container, the mare had never drunk from. After moving to an enclosure with another donkey and a different water bucket, her aggression during nursing ceased. The primary cause of foal rejection was neophobia with secondary excessive suckling by the hungry foal (Houpt and Antczak, 1998).

\section{Treatment and prevention of foal rejection}

Treatment of foal rejection aims at protecting the neonate from dam's aggression, providing continuous access to the mare's teats and stimulating maternal behaviour in the rejecting mare (Houpt, 2009).

Treatment of foal rejection usually depends on the type of abnormal maternal behaviour. For ambivalence, if both the dam and the foal are healthy, momentary separation can evaluate maternal behaviour. Foal's reaction to separation like circling and vocalizations may stimulate the dam to respond (Grogan and McDonnell, 2005). It was observed that one third of rejecting mares had actively defended their foals from threats, especially dogs (Houpt, 2009). Therefore, it is recommended to threaten the mare with a dog kept on a leash. Another method is to turn out the mare with the foal in a paddock adjacent to other horses. These techniques stimulate the maternal aggression and defensiveness and may result in acceptance of the foal (Grogan and McDonnell, 2005; Houpt, 2010). Both methods of threatening the dam should be closely monitored because the mare may accidentally injure her foal (Grogan and McDonnell, 2005).

If a mare is afraid of her foal, the pair should be moved to a larger area. It lessens the dam's fear because she is able to avoid the foal there (Grogan and McDonnell, 2005; Houpt, 2010). Then, the dam should be rewarded for calm behaviour when the foal is brought closer. Tranquilization of the mare may be helpful, but it is important to achieve it without transferring significant sedation to the neonate (Grogan and McDonnell, 2005). The methods of separating or threatening the pair which are useful for ambivalent dams are also recommended for fearful mares (Grogan and McDonnell, 2005; Houpt, 2010).

When nursing avoidance occurs, it is important to eliminate all medical causes of this behaviour, like mastitis (Houpt, 2009). If the dam's aggression is mild, she can be treated only by being restrained under halter (Grogan and McDonnell, 2005; Houpt, 2009). After three or four nursing bouts, the mare usually becomes more tolerant of further suckling. She learns that nursing is a pleasurable experience because it decreases udder pain (Crowell-Davis and Weeks, 2005; Houpt, 2009). Nursing only avoidance mares are usually tolerant of hand milking (Grogan and McDonnell, 2005). Because a neonate needs colostral antibodies to create its own passive 
immunity, it is necessary to milk the dam and feed the foal from the bottle. The bottle should be held in the mare's inguinal area. When the mare calms down, the foal should be encouraged to suckle the teats (Grogan and McDonnell, 2005; Houpt, 2009). If the mare is still aggressive during nursing, tranquilization can be beneficial (Grogan and McDonnell, 2005).

Savage attack is difficult to treat because relapses are very common (Grogan and McDonnell, 2005). Combination of several methods such as tranquilization, restraint, immediate punishment for aggression and administration of oxytocin and progestins can result in formation of a normal mare-foal bond (Grogan and McDonnell, 2005; Houpt, 2010).

The main rule of prevention of foal rejection is to limit disturbance of foaling mare as much as possible. It is suggested to allow the fetal membranes and fluids to remain with the dam for some time after parturition (Grogan and McDonnell, 2005). If a foal is ill, it is important to let the mare have visual contact with her foal during medical procedures (Grogan and McDonnell, 2005; Houpt, 2010). Finally, taking into account the genetic aspect of inadequate maternal behaviour, it is recommended not to re-breed the mares that have attacked their neonates savagely (Grogan and McDonnell, 2005).

\section{Fostering techniques}

In the first few weeks of life, a foal is dependent on the mare and the contact with other members of the herd is minimal (Crowell-Davis, 2007). But when the dam is unable or unwilling to nurse and protect her foal, it must be reared artificially (Houpt et al., 1982). There are two fostering methods: hand rearing and provision of a nurse mare.

The safest short-term method is hand rearing (Houpt, 2009). In the first hours after parturition, the aim of this solution is to provide the adequate amount of colostrum. Colostrum can be obtained from a dam (in the case of foal rejection), from a donor mare or a colostrum bank (if the foal is an orphan) (Frape, 2010; Grogan and McDonnell, 2005). Up to $250 \mathrm{ml}$ of colostrum can be collected from a donor mare without harming her own foal. After nursing, the mare should be milked from the teat which the neonate did not suckle. Harvested colostrum can be kept frozen at $-20^{\circ} \mathrm{C}$ for up to a year (Tischner, 1993; Grogan and McDonnell, 2005). The concentration of IgG should be at least $8000 \mathrm{mg}$ in $100 \mathrm{ml}$ of colostrum (Kenzig et al., 2009). At least 1 litre of good quality colostrum should be given to a foal in the first 8 hours after parturition (Pawlak and Doroz, 1998). If colostrum is unavailable, equine plasma can be used as well (Frape, 2010; Grogan and McDonnell, 2005). The best solution is to collect plasma from the blood of gelding horse which has never received a blood transfusion and which has been in the stud for some time. A total dose of approximately 1 liter per foal should be given. Aseptically intravenous dosing with plasma is preferable, but in cases of enteritis oral dosing may be helpful (Frape, 2010).

Usually, in the first week after parturition, the foal suckles every 15 minutes with short nursing bouts, lasting from 1 to 1.5 minutes (Crowell-Davis, 2007; Houpt, 2009; Żurek and Danek, 2011 b). This frequency is almost impossible to maintain in the hand-rearing method. In practice an orphan foal is fed every 2 hours (Houpt, 
2009). A diet for a fostering foal includes mare's milk from a high-producing donor mare, goat's milk, or commercial milk replacers. Cow's milk is cheap and easily available but has more fat and less sugar than mare's milk. Even altered to more closely match mare's milk, cow's milk is not well accepted by foals and can lead to indigestion (Pawlak and Doroz, 1998; Grogan and McDonnell, 2005). Milk temperature should range between $35-38^{\circ} \mathrm{C}$. In the first two days of a foal's life, the amount of milk that the foal is fed should be $10-15 \%$ of the foal's body weight. In the following days, the amount of milk given should increase so that on the seventh day of the foal's life it equals $25 \%$ of the foal's weight (Pawlak and Doroz, 1998). Also, the foal should have unlimited access to hay, grain, water and a salt block. Weaning can begin around 3-4 months with a gradual reduction in the number and volume of milk feedings (Pawlak and Doroz, 1998; Grogan and McDonnell, 2005). During rearing, the friendly geldings, nonlactating mares, or older foals can be good caretakers of an orphan and provide an opportunity to teach essential social skills (Crowell-Davis, 2007).

However, hand-rearing has many disadvantages. Firstly, the feeding frequency is difficult to maintain. It is also time-consuming for most recreational horse owners (Crowell-Davis and Weeks, 2005; Grogan and McDonnell, 2005; Houpt, 2009). What is more, milk replacers are expensive and usually unavailable (Houpt, 2009). Larger, less frequent meals consisting of mare's milk substitutes are different than a foal would normally consume and can lead to the gastrointestinal problems like diarrhoea (Houpt, 2009). Finally, bottle feeding presents the problem of possible too close human-foal bond (Crowell-Davis and Weeks, 2005; Grogan and McDonnell, 2005). Hand-reared foals usually have no fear of humans and may be difficult to handle as adult horses (Pawlak and Doroz, 1998; Houpt, 2009).

The ideal solution for an orphan or a rejected foal is to foster it onto a nurse mare (Pawlak and Doroz, 1998; Crowell-Davis and Weeks, 2005, Houpt, 2009). Nonoffspring nursing is defined as allonursing (Pluhacek et al., 2011). It provides the optimal composition, quantity and taste of milk. It also reduces stress in an orphan foal. These are the main factors that determine the proper development of a young horse (Pawlak and Doroz, 1998).

Allonursing has been observed in many mammals including ungulate species. It is the most extreme type of shared parenting (Pluhacek et al., 2011). Nevertheless, it is a very rare behaviour in horses because most mares create a specific bond with a neonate in the immediate postpartum period and they are not interested in the foals that are presented to them after this period (Crowell-Davis and Weeks, 2005; Pluhacek et al., 2011). Maternal recognition of the neonate is based on olfactory, visual, and auditory senses (Grogan and McDonnell, 2005). In close proximity, olfactory stimuli are the most important (Pawlak and Doroz, 1998; Crowell-Davis and Weeks, 2005; Grogan and McDonnell, 2005). This fact can be used to facilitate the fostering of a new foal (Crowell-Davis and Weeks, 2005; Grogan and McDonnell, 2005). It is suggested to smear the foal's body (head and tail are the most important) with amniotic fluids, mare's milk or cover the foal with amniotic membranes, a blanket worn by the mare's foal or the dead foal's skin (Pawlak and Doroz, 1998; Crowell-Davis 
and Weeks, 2005; Grogan and McDonnell, 2005). This can disguise the foal's own scent (Grogan and McDonnell, 2005). Another method is to use vaginal-cervical stimulation. The foal is held close to the mare's head while she receives a vigorous massage of the external portion of the cervix. This massage should be applied twice (2-3 min. periods) separated by a 10 min. interval (Porter et al., 2002; Daels, 2006). It is also recommended to lead the mare away from the stable and bring the foal in the mare's box before her return. The mare is more likely to accept the foal after such separation (Pawlak and Doroz, 1998; Grogan and McDonnell, 2005). The foal should be nursed soon after the first interaction with the foster mare. Hand-reared foals, which have been bottle fed for a long time, may have some problems with acceptance of suckling the mare (Grogan and McDonnell, 2005).

To ensure that the bond between the foster mare and the foal is being formed, the pair should be closely supervised during the first several hours after introducing the foal to the foster mare. In the case the mare shows aggression towards the foal, she should be restrained on a lead rope (Crowell-Davis and Weeks, 2005). Using of a simple action-reaction technique can discourage mare to respond aggressively to the foal (Daels, 2006). Depending on the mare's temperament, tranquilization can be beneficial or unnecessary (Grogan and McDonnell, 2005). When the foster mare accepts the foal, her maternal behaviour resembles that of a biological dam towards her own offspring (Porter et al., 2002).

In large studs, there is a possibility to identify a mare that will accept alien foals or even allow them to suckle (Crowell-Davis and Weeks, 2005). Such mares are valuable in horse-breeding and are kept in studs as nurse mares (Crowell-Davis and Weeks, 2005). A foster or nurse mare should be an experienced mother with appropriate milk production. The perfect solution for an orphaned foal is a nurse mare, that is similar to the foal's biological dam in terms of size and breed. The composition and amount of milk is the best for foal when a nurse mare is in the same stage of lactation as the foal's dam. The ideal nurse mare is also accustomed to being restrained, having the udder palpated, and standing in a straight stall (Grogan and McDonnell, 2005).

It is possible to induce maternal behaviour and lactation in non-parturient mares (Porter et al., 2002; Daels, 2006; Houpt, 2009). The best solution is to choose a mare in a good body condition, free of disease and mammary gland abnormalities. That mare must have raised at least one foal and showed normal maternal behaviour in previous years (Daels, 2006). The induction of maternal behaviour can be achieved through a combination of hormonal manipulations, interaction with a neonate and human intervention, if necessary (Porter et al., 2002). Hormonal treatment involves administration of estrogen, progesterone and a dopamine D2 antagonist (sulpiride or domperidone) (Daels, 2006; Houpt, 2009). Usually, milking is started in the first week of treatment. The mare is ready for adoption when daily milk production reaches 3-5 litres (Daels, 2006).

\section{Conclusion}

Abnormal maternal behaviour in mares leads to a loss of time and money for breeders; therefore, it is important to learn about the prevention rules (Juarbe-Diaz et al., 1998). Foal rejection is quite rare but if it occurs, it is necessary to make prompt 
decisions and assessments on whether to keep the pair of mare and foal or not. It requires breeders to understand the type of inadequate maternal behaviour, typical treatment and potential consequences of human intervention (Grogan and McDonnell, 2005).

\section{References}

C a m e ro n E.Z., L in k l a t e r W.L., S t a f for d K.J., M in o t E.O. (2003). Social grouping and maternal behaviour in feral horses (Equus caballus): the influence of males on maternal protectiveness. Behav. Ecol. Sociobiol., 53: 92-101.

Crowe 11-D a vis S.L. (2007). Understanding behavior: Understanding foal development and its relevance to raising orphaned foals. Comp. Equine, 6: 318-323.

Crowe 11 - D a vis S.L., Houpt K.A. (1986). Maternal behavior. Vet. Clin. N. Am.-Equine, 2: $557-571$.

Crowe 11-Davis S.L., W e k s J. (2005). Maternal behaviour and mare-foal interaction. In: The domestic horse: the origins, development, and management of its behaviour, Mills D.S., McDonnell S.M. (eds). Cambridge, USA, Cambridge University Press, pp. 126-138.

D a e ls F.P. (2006). Induction of lactation and adoption of the orphan foal. Proc. 8th AAEP Annual Resort Symposium, Rome, Italy, 19-21.01.2006.

Fr a pe D. (2010). Equine nutrition and feeding. Ames, USA, Wiley-Blackwell, 4th ed., pp. 198-201.

Grog a n E.H., M c D on nell S.M. (2005). Mare and foal bonding and problems. Clin. Tech. Equine Pract., 4: 228-237.

H o u p t K.A. (2009). Foal rejection. In: Current therapy in equine medicine, Robinson N.E., Sprayberry K.A. (eds). St. Louis, USA, Saunders Elsevier, pp. 116-118.

H o u p t K.A. (2010). Domestic animal behavior for veterinarians and animal scientists. Ames, USA, Wiley-Blackwell, 5th ed., pp. 135-163.

Houpt K.A., Antczak D. (1998). Abnormal maternal behavior in a donkey as a consequence of neophobia. Appl. Anim. Behav. Sci., 2: 259-262.

H o u p t K.A., P a r s on s M.S., H in t z H.F. (1982). Learning ability of orphan foals, of normal foals and of their mothers. J. Anim. Sci., 55: 1027-1032.

Juarbe-Diaz S.V., Houpt K.A., Kusunose R. (1998). Prevalence and characteristics of foal rejection in Arabian mares. Equine Vet. J., 30: 424-428.

Kenzig A.R., O'M e a r a K.M., Kre m er C.J., J o g a n K.S., J a c k N.E., C ol e K. (2009). Colostral, milk and serum immunoglobulin $\mathrm{G}$ concentrations in Quarter Horse mares and their foals. J. Equine Vet. Sci., 5: 486-487.

M e 11 o r D.J., S t a ffor d K.J. (2004). Animal welfare implications of neonatal mortality and morbidity in farm animals. Vet. J., 168: 118-133.

P aw la k M., D or o z M. (1998). Raising orphan foals (in Polish). Med. Wet., 54: 737-740.

Pluha cek J., B artos L. (2000). Male infanticide in captive plains zebra, Equus burchelli. Anim. Behav., 59: 689-694.

Pluhacek J., B artos ova J., B artos L. (2011). A case of adoption and allonursing in captive plains zebra (Equus burchellii). Behav. Processes., 86: 174-177.

P orter R.H., D u cha m p G., N ow a k R., D a els P.F. (2002). Induction of maternal behavior in non-parturient adoptive mares. Physiol. Behav., 77: 151-154.

T is ch ne r M. (1993). Health and its threats during the first 24 hours of foal's life. In: Prevention and therapy in animals rearing (in Polish), T. Bakuła (ed.). Akademia Rolniczo-Techniczna, Olsztyn, pp. 135-141.

Żurek U., D a ne k J. (2011 a). Maternal behaviour in mares. Med. Wet., 67: 394-396.

$\dot{Z}$ ur e k U., D a n e k J. (2011 b). Maternal behaviour in mares and the condition of foals after parturition. B. Vet. Inst. Pulawy, 55: 451-456. 
URSZULA ŻUREK, JANUSZ DANEK

Odrzucanie źrebiąt - charakterystyka i terapia nieodpowiednich zachowań matczynych u klaczy

\section{STRESZCZENIE}

Więź między klaczą a jej nowo narodzonym źrebięciem jest zazwyczaj bardzo silna. Czasami pewne czynniki mogą prowadzić do zaburzeń w zachowaniu matczynym. Brak opieki nad źrebięciem i uniemożliwienie mu pobierania siary definiuje się jako odrzucenie źrebięcia. Długi okres ciąży i coraz wyższa wartość źrebiąt sprawiają, że odrzucenie źrebięcia powoduje duże straty dla hodowcy. Właściciele i hodowcy koni powinni mieć wiedzę na temat nieprawidłowego zachowania matczynego u klaczy, ryzyka jego wystąpienia oraz sposobów zapobiegania i leczenia. W przypadku wystąpienia odrzucenia źrebięcia bardzo ważne jest zastosowanie odpowiednich technik wychowu odrzuconych źrebiąt. 